\title{
Quality Control of Baculoviral Bioinsecticide Production
}

\author{
Solange Ana Belén Miele, Mariano Nicolás Belaich, \\ Matías Javier Garavaglia and Pablo Daniel Ghiringhelli \\ LIGBCM-AVI (Laboratorio de Ingeniería Genética y \\ Biología Celular y Molecular - Area Virosis de Insectos) \\ Universidad Nacional de Quilmes/Departamento de Ciencia y Tecnología \\ Argentina
}

\section{Introduction}

Agriculture is a discipline that has accompanied human beings since the beginning of civilization. The cultivation of different vegetables for centuries has allowed selecting varieties that far exceed the capabilities of many wild type plants originally used as a food source. That situation derived in the manipulation of natural ecosystems, transforming them into spaces where they can only grow and develop the desired species.

In our world, plants are the staple diet of many organisms including invertebrates like Lepidoptera. During the larval stage, these insects can consume a large amount of leaf tissue causing serious damage to the plant. If we think that most vegetables have insect predators, agricultural crops can be transformed into an inviting habitat, allowing the development of these animals. In conclusion, all crops have pests that threaten their productivity. Given this scenario, many pest control strategies have been used by human beings to protect the health of their crops: treatment with chemical insecticides, development of transgenic plants and biological control applications (Christou et al, 2006; Gilligan, 2008).

Baculovirus is a large family of insect pathogens that infect and kill different species of Lepidoptera, Hymenoptera and Diptera (Theilmann et al, 2005). In particular, many lepidopteron are pests in agriculture transforming these viruses in an important biocontrol tools for their natural hosts (Entwistle, 1998; Moscardi, 1999; Szewczyk et al, 2006). Baculoviruses have double-stranded circular DNA genomes of 80,000-180,000 bp, containing between 80 to 180 genes depending on the specie (van Oers \& Vlak, 2007; Miele et al, 2011). In early stages of virus cycle, this pathogen is produced as Budded Viruses (BVs): the genome contained in a protein capsid (nucleocapsid), which is surrounded by a lipid membrane. In change, in the last phase of multiplication processes appear the Occluded Bodies (OBs): protein crystals (forming polyhedra or granules) containing nucleocapsids wrapped by a lipid membrane with a different composition (ODVs or Occluded Derived Viruses, with single or multiple nucleocapsids depending on the specie) (Rohrman, 2008). These two virus phenotypes have different biological properties; while OBs are specialists (infecting larvae by per os route with a narrow host range; responsible of primary infection in midgut cells), the BVs are generalists (infecting a wide range of different insect cells triggering their death; responsible for secondary infection). In the pest control strategies, baculoviruses (OBs) are introduced on the crops to infect and kill larvae through the production of an epizooty. 


\begin{tabular}{|c|c|c|c|c|c|}
\hline Genus & Name & Code & $\begin{array}{l}\text { Accesion } \\
\text { number }\end{array}$ & $\begin{array}{c}\text { Genome } \\
(\mathrm{bp})\end{array}$ & $\begin{array}{l}\text { Total } \\
\text { ORFs } \\
\end{array}$ \\
\hline \multirow{14}{*}{ 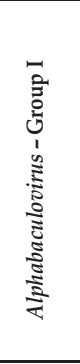 } & Antheraea pernyi NPV-Z & APN & NC_008035 & 126629 & 145 \\
\hline & Antheraea pernyi NPV-L2 & AP2 & EF207986 & 126246 & 144 \\
\hline & Anticarsia gemmatalis MNPV-2D & AGN & NC_008520 & 132239 & 152 \\
\hline & Autographa californica MNPV-C6 & $\mathrm{ACN}$ & NC_001623 & 133894 & 154 \\
\hline & Bombyx mori NPV & $\mathrm{BMN}$ & NC_001962 & 128413 & 137 \\
\hline & Bombyx mandarina NPV & $\mathrm{BON}$ & NC_012672 & 126770 & 141 \\
\hline & Choristoneura fumiferana DEF MNPV & CDN & NC_005137 & 131160 & 149 \\
\hline & Choristoneura fumiferana MNPV & CFN & NC_004778 & 129593 & 145 \\
\hline & Epiphyas postvittana NPV & EPN & NC_003083 & 118584 & 136 \\
\hline & Hyphantria cunea NPV & $\mathrm{HCN}$ & NC_007767 & 132959 & 148 \\
\hline & Maruca vitrata MNPV & MVN & NC_008725 & 111953 & 126 \\
\hline & Orgyia pseudotsugata MNPV & OPN & NC_001875 & 131995 & 152 \\
\hline & Plutella xylostella MNPV & $\mathrm{PXN}$ & NC_008349 & 134417 & 149 \\
\hline & Rachiplusia ou MNPV & RON & NC_004323 & 131526 & 146 \\
\hline \multirow{27}{*}{ 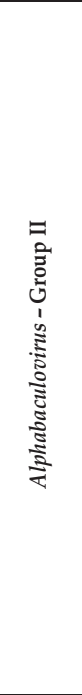 } & Adoxophyes honmai NPV & AHN & NC_004690 & 113220 & 125 \\
\hline & Adoxophyes orana NPV & AON & NC_011423 & 111724 & 121 \\
\hline & Agrotis ipsilon NPV & AIN & NC_011345 & 155122 & 163 \\
\hline & Agrotis segetum NPV & ASN & NC_007921 & 147544 & 153 \\
\hline & Apocheima cinerarium NPV & $\mathrm{APO}$ & FJ914221 & 123876 & 118 \\
\hline & Chrysodeixis chalcites NPV & $\mathrm{CCN}$ & NC_007151 & 149622 & 151 \\
\hline & Clanis bilineata NPV & $\mathrm{CBN}$ & NC_008293 & 135454 & 129 \\
\hline & Ectropis obliqua NPV & EON & NC_008586 & 131204 & 126 \\
\hline & Euproctis pseudoconspersa NPV & EUN & NC_012639 & 141291 & 139 \\
\hline & Helicoverpa armigera NPV-C1 & HA1 & NC_003094 & 130759 & 135 \\
\hline & Helicoverpa armigera NPV-G4 & HA4 & NC_002654 & 131405 & 135 \\
\hline & Helicoverpa armigera MNPV & HAN & NC_011615 & 154196 & 162 \\
\hline & Helicoverpa armigera SNPV-NNg1 & HAS & NC_011354 & 132425 & 143 \\
\hline & Helicoverpa zea SNPV & HZN & NC_003349 & 130869 & 139 \\
\hline & Leucania separata NPV-AH1 & LSN & NC_008348 & 168041 & 169 \\
\hline & Lymantria dispar MNPV & LDN & NC_001973 & 161046 & 163 \\
\hline & Lymantria xylina MNPV & LXN & NC_013953 & 156344 & 157 \\
\hline & Mamestra configurata NPV-90-2 & MCN & NC_003529 & 155060 & 169 \\
\hline & Mamestra configurata NPV-90-4 & MC4 & AF539999 & 153656 & 168 \\
\hline & Mamestra configurata NPV-B & $\mathrm{MCB}$ & NC_004117 & 158482 & 169 \\
\hline & Orgyia leucostigma NPV & OLN & NC_010276 & 156179 & 135 \\
\hline & Spodoptera exigua MNPV & SEN & NC_002169 & 135611 & 142 \\
\hline & Spodoptera frugiperda MNPV-3AP2 & SF2 & NC_009011 & 131330 & 143 \\
\hline & Spodoptera frugiperda MNPV-19 & SF9 & EU258200 & 132565 & 141 \\
\hline & Spodoptera litura NPV-II & SLN & NC_011616 & 148634 & 147 \\
\hline & Spodoptera litura NPV-G2 & SL2 & NC_003102 & 139342 & 141 \\
\hline & Trichoplusia ni SNPV & TNN & NC_007383 & 134394 & 144 \\
\hline \multirow{12}{*}{ 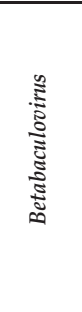 } & Adoxophyes orana $\mathrm{GV}$ & AOG & NC_005038 & 99657 & 119 \\
\hline & Agrotis segetum $\mathrm{GV}$ & ASG & NC_005839 & 131680 & 132 \\
\hline & Choristoneura occidentalis GV & COG & NC_008168 & 104710 & 116 \\
\hline & Cryptophlebia leucotreta GV & CLG & NC_005068 & 110907 & 129 \\
\hline & Cydia pomonella $\mathrm{GV}$ & CPG & NC_002816 & 123500 & 143 \\
\hline & Helicoverpa armigera GV & HAG & NC_010240 & 169794 & 179 \\
\hline & Phthorimea operculella GV & POG & NC_004062 & 119217 & 130 \\
\hline & Plutella xylostella GV & PXG & NC_002593 & 100999 & 120 \\
\hline & Pieris rapae GV & PRG & GQ884143 & 108592 & 120 \\
\hline & Pseudaletia unipuncta GV-Hawaiin & PUG & EU678671 & 176677 & 183 \\
\hline & Spodoptera litura GV-K1 & SLG & NC_009503 & 124121 & 136 \\
\hline & Xestia c-nigrum GV & $\mathrm{XCG}$ & NC_002331 & 178733 & 181 \\
\hline \multirow{3}{*}{$\underset{\mathrm{S}}{\stackrel{5}{\Xi}}$} & Neodiprion abietis NPV & NAN & NC_008252 & 84264 & 93 \\
\hline & Neodiprion lecontei NPV & NLN & NC_005906 & 81755 & 93 \\
\hline & Neodiprion sertifer NPV & NSN & NC_005905 & 86462 & 90 \\
\hline Delta & Culex nigripalpus NPV & $\mathrm{CNN}$ & NC_003084 & 108252 & 109 \\
\hline
\end{tabular}

Table 1. Baculovirus complete genomes. Baculoviruses used in this study, sorted by genus (and within them by alphabetical order). MNPV is the abbreviation of multicapsid nucleopolyhedrovirus; NPV is the abbreviation of nucleopolyhedrovirus; SNPV is the abbreviation of single nucleopolyhedrovirus; GV is the abbreviation of granulovirus. The accession numbers are from National Center for Biotechnology Information (NCBI, http://www.ncbi.nlm.nih.gov) and correspond to the sequences of complete genomes. Code is an acronym used for practicity 


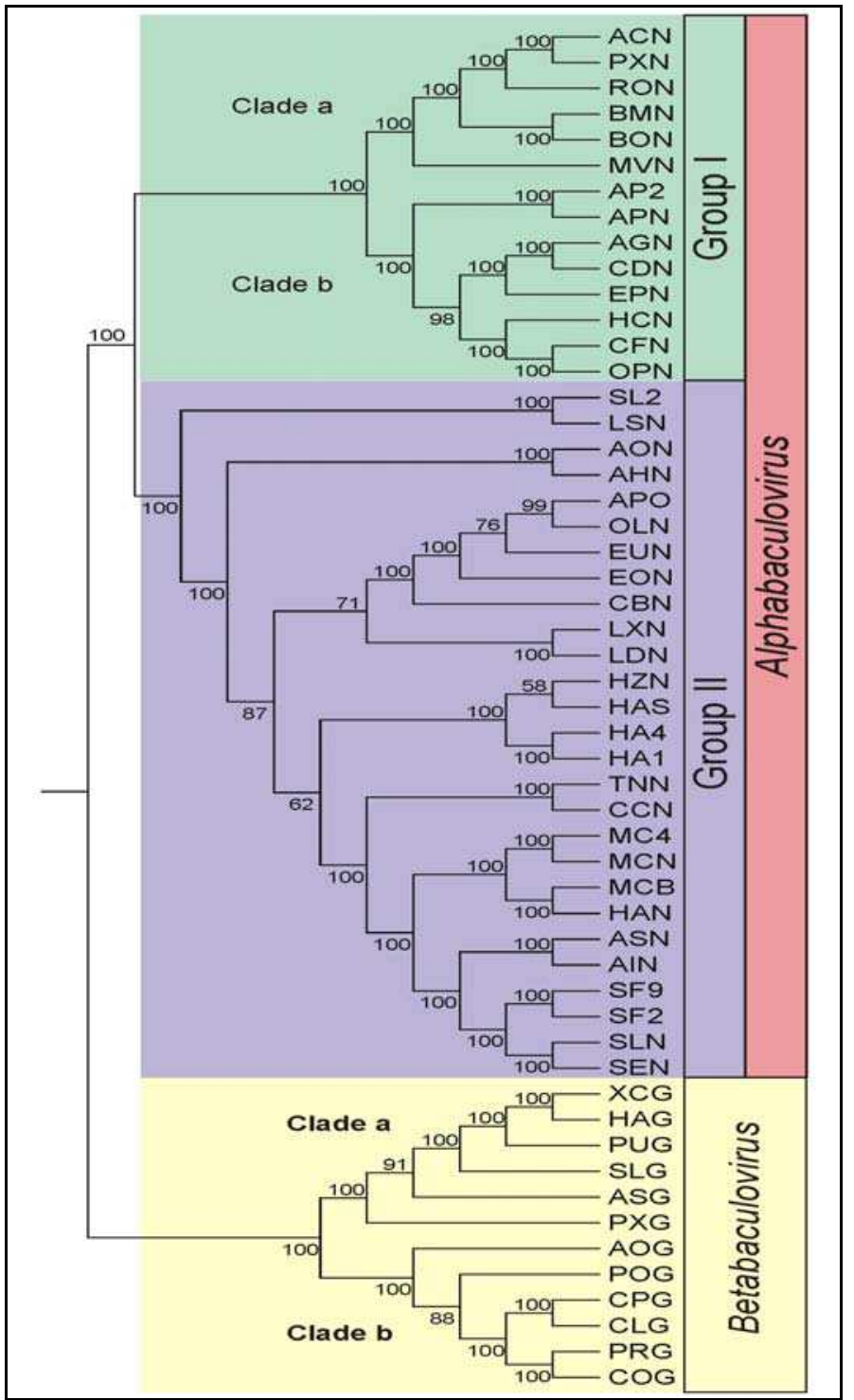

Fig. 1. Lepidopteron Baculovirus genome phylogeny. Cladogram based on amino acid sequence of 31 core genes. Core genes from Lepidopteron Baculoviridae family were independently aligned using MEGA 4 (GOP = 10, GEP $=1$ and Dayhoff Matrix. Then, a concatemer was generated and phylogeny inferred using the same software [UPGMA; Bootstrap with 1000 replicates; gap/Missing data = complete deletion; Model = Amino (Dayhoff Matrix); patterns among sites $=$ Same; rates among sites $=$ Different $($ Gamma Distributed); gamma parameter $=2.25]$. Baculoviruses are identified by the acronyms given in Table 1 and distribution in lineages and genera are also indicated. Clades proposed for Betabaculoviruses are shown in bold letters (Miele et al, 2011) 


\begin{tabular}{|c|c|c|}
\hline Virus code & Host (larvae) & Pest of... \\
\hline $\mathrm{ACN}$ & $\begin{array}{l}\text { Alfalfa looper, broad } \\
\text { host range }\end{array}$ & Alfalfa and many other crops \\
\hline AGN & $\begin{array}{l}\text { Velvetbean } \\
\text { caterpillar }\end{array}$ & Soybean crops \\
\hline AHN & Smaller tea tortrix & Tea plants \\
\hline AIN & Black cutworm & $\begin{array}{c}\text { Vegetables, solanaceous, cucurbitaceous and } \\
\text { industrial crops (cotton, essential-oil cultures, } \\
\text { maize, tobacco, sunflower) }\end{array}$ \\
\hline AOG & $\begin{array}{l}\text { Summer fruit tortrix } \\
\text { moth }\end{array}$ & Apples and pears \\
\hline AON & Tea tree tortrix & $\begin{array}{l}\text { Apple, pear, rose, plum, cherry, apricot, sweet } \\
\text { cherry, currant, gooseberry, etc. }\end{array}$ \\
\hline ASG & Black cutworm & $\begin{array}{l}\text { Cotton, essential-oil cultures, maize, tobacco, } \\
\text { sunflower, tomatoes, sugar beet and potato and } \\
\text { also damage seedlings of tree species }\end{array}$ \\
\hline ASN & Turnip moth & $\begin{array}{c}\text { Many vegetable and field crops (corn, rape, beet, } \\
\text { potatoes, cabbage, cereals, tobacco, vine and many } \\
\text { others) }\end{array}$ \\
\hline CBN & Clanis bilineata & Soybean \\
\hline $\mathrm{CCN}$ & Chrysodeixis chalcites & Tomato and sweet pepper. \\
\hline CDN, CFN & $\begin{array}{c}\text { Eastern spruce } \\
\text { budworm }\end{array}$ & Conifeorus trees \\
\hline CLG & $\begin{array}{l}\text { False codling moth, } \\
\text { other Tortricid }\end{array}$ & Citrus, cotton, maize \\
\hline COG & $\begin{array}{l}\text { Western spruce } \\
\text { budworm }\end{array}$ & Coniferous trees \\
\hline CPG & Codling moth & Apples, pear and quince \\
\hline EON & $\begin{array}{l}\text { The tea looper } \\
\text { caterpillar }\end{array}$ & Tea plants \\
\hline EPN & $\begin{array}{l}\text { Light brown apple } \\
\text { moth }\end{array}$ & Apple, horticultural crops \\
\hline $\begin{array}{l}\text { HA1, HAN, } \\
\text { HAS, HAG }\end{array}$ & Old world bollworm & $\begin{array}{l}\text { Cotton, corn, baccy, tomato, maize, chick pea, } \\
\text { alfalfa, soybean, pea, pumpkin }\end{array}$ \\
\hline $\mathrm{HCN}$ & Fall webworm & Trees (cherry, plane, mulberry and persimmon) \\
\hline LDN & Gypsy moth & Hardwoods \\
\hline
\end{tabular}




\begin{tabular}{|c|c|c|}
\hline Virus code & Host (larvae) & Pest of... \\
\hline LSN & Eastern armyworm & Many field crops in China \\
\hline LXN & Casuarina moth & Casuarina, guava, longan, lychee, acacia \\
\hline $\begin{array}{c}\mathrm{MCN} \\
\mathrm{MC4}, \mathrm{MCB}\end{array}$ & Bertha armyworm & Cruciferous oilseed crops in Canada. \\
\hline MVN & Maruca pod borer & $\begin{array}{l}\text { Leguminous crops (pigeon pea, cowpea, mung } \\
\text { bean and soybean) }\end{array}$ \\
\hline OLN & $\begin{array}{l}\text { White-marked } \\
\text { tussock moth }\end{array}$ & Wide variety of trees, deciduous and coniferous \\
\hline POG & Potato tuber moth & $\begin{array}{l}\text { Solanaceous cultures (potato, eggplant, tomato, } \\
\text { pepper, and tobacco). }\end{array}$ \\
\hline PRG & Small cabbage white & $\begin{array}{l}\text { Cabbage, swede, turnip, radish, horseradish, } \\
\text { garden radish, watercress, rape, turnip, and other } \\
\text { cruciferous plants }\end{array}$ \\
\hline PUG & Armyworm & $\begin{array}{l}\text { Turfgrasses, small grains, corn, timothy, millet, and } \\
\text { some legumes }\end{array}$ \\
\hline PXG, PXN & Diamondback moth & Cruciferous crops \\
\hline RON & Gray looper moth & Herbaceous plants \\
\hline SEN & Beet armyworm & $\begin{array}{l}\text { Asparagus, beans and peas, sugar and table beets, } \\
\text { celery, cole crops, lettuce, potato, tomato, cotton, } \\
\text { cereals, oilseeds, tobacco, etc. }\end{array}$ \\
\hline SF2, SF9 & Fall armyworm & Corn and small grain crops \\
\hline $\begin{array}{l}\text { SLN, SL2, } \\
\text { SLG }\end{array}$ & $\begin{array}{l}\text { Oriental leafworm } \\
\text { moth }\end{array}$ & Wide range of plants, like cotton and tobacco. \\
\hline TNN & Cabbage looper & $\begin{array}{l}\text { Wide variety of cultivated plants and weeds } \\
\text { (broccoli, cabbage, cauliflower, collards, kale, } \\
\text { mustard, radish, rutabaga, turnip, snap bean, } \\
\text { spinach, squash, sweet potato, tomato, watermelon, } \\
\text { etc.) }\end{array}$ \\
\hline XCG & $\begin{array}{l}\text { Setaceous hebrew } \\
\text { character }\end{array}$ & $\begin{array}{l}\text { Huge variety of plants (tomato, tobacco, carrot, } \\
\text { lettuce, alfalfa, potato, grape, maize, apple) }\end{array}$ \\
\hline
\end{tabular}

Table 2. Baculovirus and pest control. The table contains some Baculoviruses with their insect hosts, revealing their possible application as bioinsecticide

Actually, baculoviruses are classified in four genera according to their biological properties and gene content: Alphabaculovirus, polyhedroviruses that infect Lepidoptera (grouped into two lineages, Group I and Group II, according to their phylogenetic relationships and the identity of the fusogenic membrane protein presents in the BVs); Betabaculovirus, 
granuloviruses that infect Lepidoptera; Gammabaculovirus, polyhedroviruses that infect Hymenoptera; and Deltabaculovirus, polyhedroviruses that infect Diptera (Table 1) (Jehle et al, 2006a).

Genomic sequence is known more than 50 different baculovirus species, being the recognized prototypes of each genus: AcMNPV, CpGV, NeleNPV and CuniNPV, respectively. Many of them have been used for biological pest control, being excellent biopesticides (Figure 1; Table 2).

However, most baculoviruses cannot efficiently compete with chemical insecticides, especially in the time of death. To overcome this problem, many researchers have been focused to introduce genetic modifications in order to accelerate the lethal effects of bioinsecticide or expand their host range. One strategy that has been explored is the introduction of genes encoding insect toxins, such as different neurotoxins from eukaryotic organism or the bacterial protein Cry (Inceoglu et al, 2006; Jinn et al, 2006; De Lima et al, 2007). Thus, these genetically modified viruses (GMV) would ensure better performance in biopesticide application.

Baculoviruses are produced by infection processes in susceptible larvae or in in vitro cell cultures. First approach is appropriate and inexpensive in small-scale, but big productions prefer the use of cell bioreactors(van Beek \& Davis, 2007; Micheloud et al, 2009; Mengual Gómez et al, 2010). This technology would allow the standardization of production processes and achieve bioinsecticides with reproducible quality.

The main difference among these strategies consists in the starters used, being in one case OBs (in larvae) and BVs in the other (in vitro cell cultures); but always with the goal of producing OBs (infective phenotype in nature). Although the trend is moving toward baculovirus production in cell cultures, it is important to note some problems associated with that strategy. One of them is the genome stability. Because only the BVs infect cells growing in laboratory conditions, after successive rounds of infection tend to accumulate defective viral variants with smaller genomes (Lee \& Krell, 1992). These quasispecies lose genomic segments encoding late proteins important for generating OBs, because there is no selection pressure associated with oral infection in larvae. Other problems are related to the composition of culture media and the availability of susceptible insect cell lines to each baculovirus. Actually, many researchers are working on the establishment of new cell lines or modifying existing ones to improve their performance, while others have focused on developing proper and cheaper formulations of growth media for cell propagation in vitro (Agathos, 2007; Micheloud et al, 2009).

\section{Quality control assays}

The production of baculoviruses for use as bioinsecticides required quality control processes to ensure their proper formulation. In either case above (wild type viruses or GMVs) or regardless of production method applied (larvae or in vitro cell cultures), is necessary to carry out a series of phenotypic and genotypic tests against which to assess the quality of each batch produced (Figure 2).

The formulation of one biological entity for some biotechnological application (e.g. baculovirus for agriculture pest control) requires its multiplication under controlled conditions and subsequent procedures for isolation and concentration. In this point, it is important to remember that all biological entities are object of evolution, natural phenomenon that can 
influence and alter the biological properties of the product by the accumulation of point mutation or genome rearrangements.
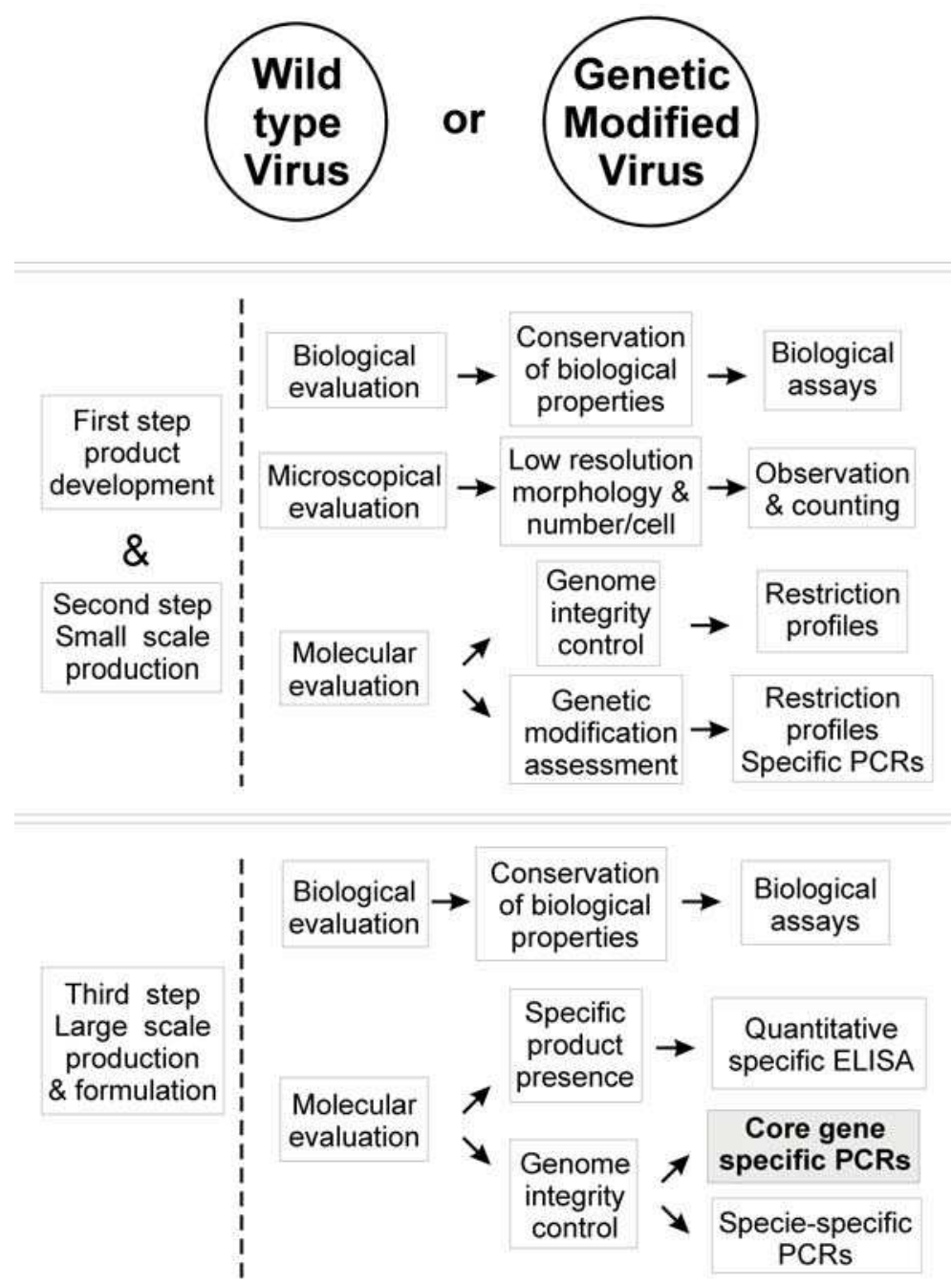

Fig. 2. Quality control scheme. A good quality control strategy is supported in the setting of and in the rigid adhesion to the procedures and protocols. These may include routine examinations of insect/cells stocks, microscopic examinations for infections, routine counting of ODVs, bioassays to assess bioinsecticide potency, restriction profiles of viral DNAs, and so on. First and second steps are developmental phases of the bioinsecticide production, in which the feasibility to obtain high amounts of good quality DNA is not an obstacle. In the third step, is of special importance the availability of sensitive molecular techniques to minimize the interference of formulation components 
Thus, quality control assays emerge as central tools for verifying the baculovirus production in each of its stages allowing generating a product that can compete with chemical insecticides, whose production is highly optimized and controlled for years. Also, quality control strategies are useful to standardize the basic studies performed in laboratory scale, necessary for the generation of improved baculovirus.

\subsection{Phenotype quality controls}

First of all, it is important to have good methods to quantify the number of OBs produced and isolated from larvae or in vitro cell cultures. To fulfill this purpose, it is possible to make direct eye count using hemocytometer and optical microscopes. On the other hand, there are methodologies based on immunoassays or carried out by the use of flow cytometers. In the first case, the development of ELISA kits or other similar tests based on the immune detection of OBs (through the use of polyclonal or monoclonal antibodies against polyhedrin or granulin proteins) has standardized the quantitation of baculovirus allowing a more reliable measure (Parola et al, 2003). The use of flow cytometers also provides good results, but only so far for the quantification of BVs (Shen et al, 2002; Jorio et al, 2006).

Once quantified the production of OBs, should determine their biological activity. This involves setting parameters to estimate the ability of baculovirus to kill insect pests and control their population. In view of this, parameters like median lethal time (LT 50) and median lethal dose (LD 50) work as the best indicators to characterize the baculovirus activity (Li \& Bonning, 2007; Lasa et al, 2008). These tests consist of exposing susceptible larvae reared in standardized conditions of temperature, light, moisture and food to the virus under evaluation. Then, through the register of deaths and the time in which they occur can be estimated both parameters.

\subsection{Genotype quality controls}

The production of baculoviruses for use as bioinsecticides requires accurate determination of the number of OBs and their biological activity expressed in LT 50 and LD 50 parameters. But it is also important to apply other methodologies that allow considering genotypic evaluations. As mentioned earlier, the processes of baculovirus production in insect cell lines growing in laboratory conditions may derived in problems with the integrity of their genomes. Consequently, the productivity of OBs can be seriously affected both in quantity and activity ruining the entire production. Of course, this is particularly relevant when dealing with GMVs. The stability of putative transgenes should be considered.

Most of baculoviruses applied as bioinsecticides derived from homogenous populations cloned or partially cloned by different procedures (Wang et al, 2003; Simón et al, 2004). This is a remarkable aspect since it allows establishing genotypic characteristic patterns that can be detected by different approaches. Among them, the visualization of RFLPs (Restriction Fragment Lenght Polymorphism) in agarose gel electrophoresis stained by different dyes and UV exposition is usually a good indicator of genome integrity, revealing the gain or loss of DNA (Simón et al, 2004; Eberle et al, 2009; Rowley et al, 2010). In fact, this is a classic approach to characterize genotypic variants of a viral species. The main problem that has this strategy is related to allocate part of baculovirus production to perform the isolation of viral genome, requiring high DNA masses to achieve reliable results. The complementation with hybridization assays solves part of that problem but requires the availability of suitable probes, adding experimental steps and costs of supplies and equipment. 
In view of that, methodologies based on PCR (Polymerase Chain Reaction) are suitable and reproducible approaches to assess baculovirus productions because this technique can detect desired locus with high sensitivity and specificity. These characteristics transform the PCR in the best genotypic evaluation strategy due to its simple, fast and accessible properties for any laboratory production. Since the beginning of studies on the baculovirus genomes, many researchers have designed PCR tests to detect, identify and classify the different species of this virus Family. Thus, PCR assays based on polyhedrin/granulin, $p 74$, lef8, lef9 or DNA polymerase genes, among others, were used to describe new virus isolates which are candidates to bioinsecticide applications (Faktor et al, 1996; de Moraes et al, 1999; Wang et al, 2000; Rosisnki et al, 2002; Espinel-Correal et al, 2011; Rodríguez et al, 2011).

However, there are too many examples of the use of PCR as a technique for quality control in the production of a baculovirus, despite all the advantages mentioned above (Christian et al, 2001; Murillo et al, 2006).

\subsubsection{MP-PCR to control baculovirus production}

PCR amplification of several loci in the same reaction allows obtaining a profile of products that can be used for genome identification or control test in production processes. MP-PCR (Multiplex PCR) assays require the proper design of primers to amplify a set of fragments that are typical for a particular genome. This technique provides results composed of a set of enzymatic amplified fragments that are characteristic for a viral species (when primers were designed completely specific), or for a phylogenetic group (when primers derived from multiple alignments of orthologous sequences). With regard to trials designed to particular viruses, it should be noted the work developed for EpapGV (Manzán et al, 2008). Meanwhile, for the detection of groups of related viruses are not many references. Currently, the accepted practice to identify or preliminarily classify a new baculovirus is based on PCR amplification and subsequent sequencing of three genomic fragments corresponding to the polyhedrin/granulin, lef9 and lef8 genes (Jehle et al, 2006b). However, this approach is not itself an MP-PCR. In view of this, we propose an MP-PCR for alpha and betabaculovirus quality control based on universal primer designs.

Baculoviruses contain 31 core genes conserved by all known members (Miele et al, 2011). These orthologous sequences are present in each sequenced baculovirus, but their genomic distribution varies among species. From the analysis of gene distribution in genus prototypes pif2, $p 49, p 74$, lef9, 38k genes were selected to primer design targets (Figure 3).

These sequences are properly distributed throughout the entire circular genome. Two genes (pif2 and $p 74$ ) encode per os infectivity factors essentials to the success of primary infection in midgut cells (Song et al, 2008; Peng et al, 2010). Other two genes ( $p 49$ and $38 \mathrm{~K}$ ) encode proteins associated to packaging, assembly, and release of virions (Wu et al, 2008; Lin et al, 2010). Meanwhile, lefg gene encodes a polypeptide involved in virus transcription machinery (Crouch et al, 2007). Using multiple alignments derived from sequences corresponding to P74, lef9 and 38k genes from all alpha and betabaculovirus members were selected the two better regions of homology to design a set of primers (Figure 4). Thus, these three amplicons certified the presence of lepidopteron baculovirus DNA.

In change, because high divergence of pif 2 and $p 49$ sequences the primer design was conducted using multiple alignments derived from closest phylogenetic clades (Group I and Group II alphabaculovirus, and betabaculovirus). According to this, different pairs of primers were designed to generate amplicons from baculovirus genomes (Figure 5). 

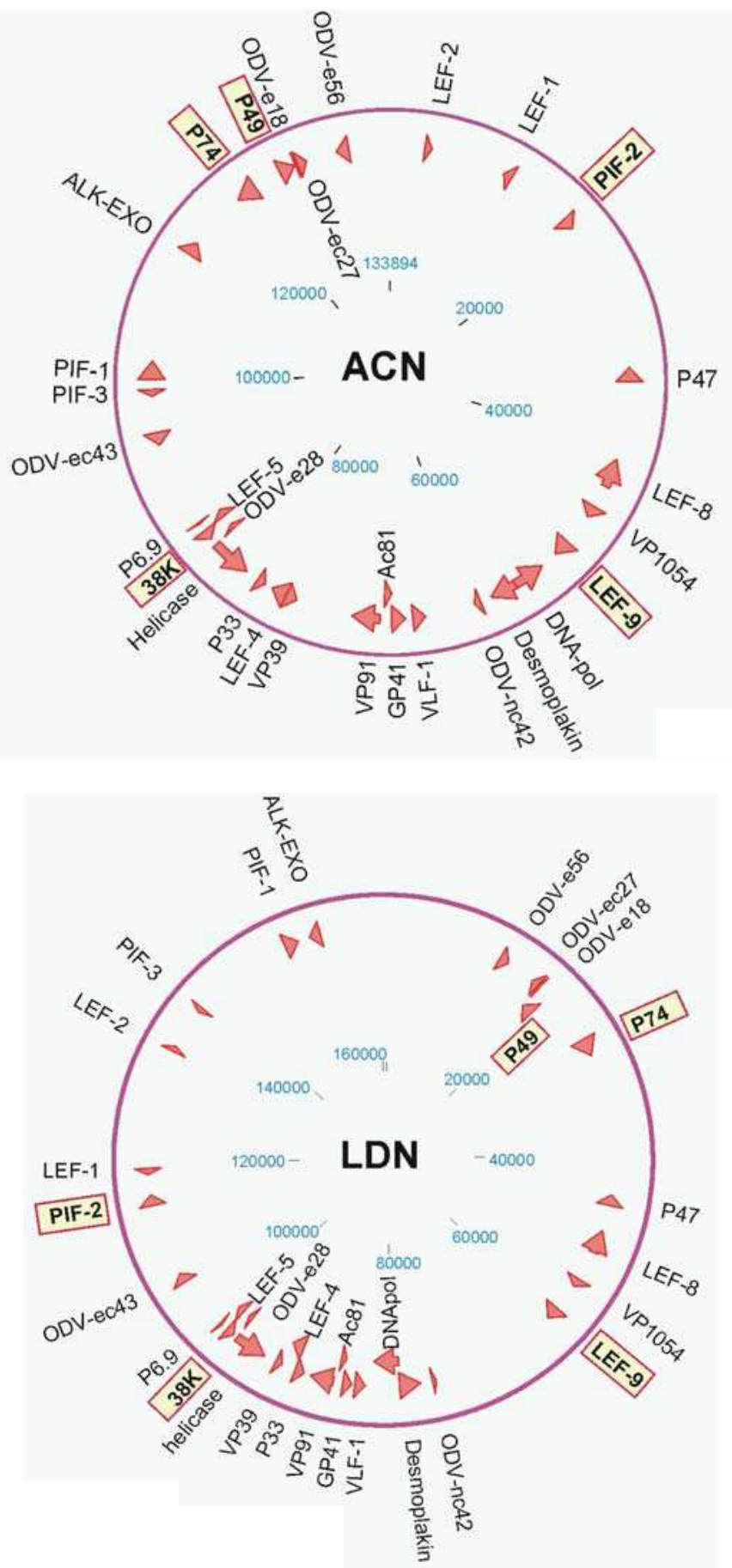


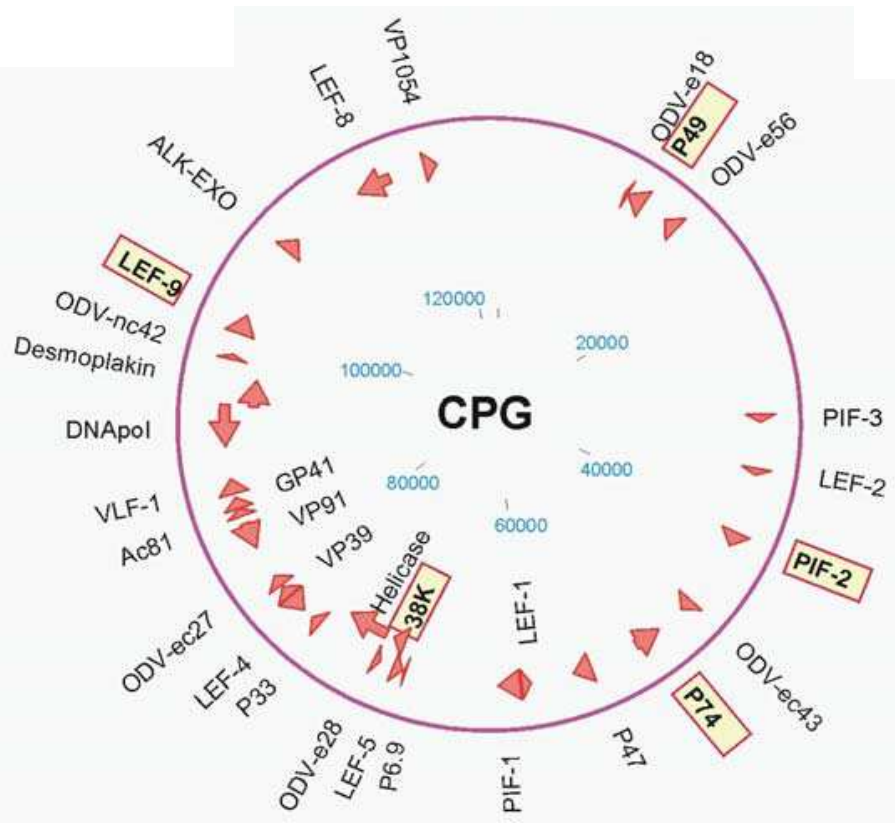

Fig. 3. Physical maps of ACN, LDN and CPG (Arrows shows the physical location of the 31 Core genes. The five selected Core genes for primer designs are highlighted in bold and red boxed.)

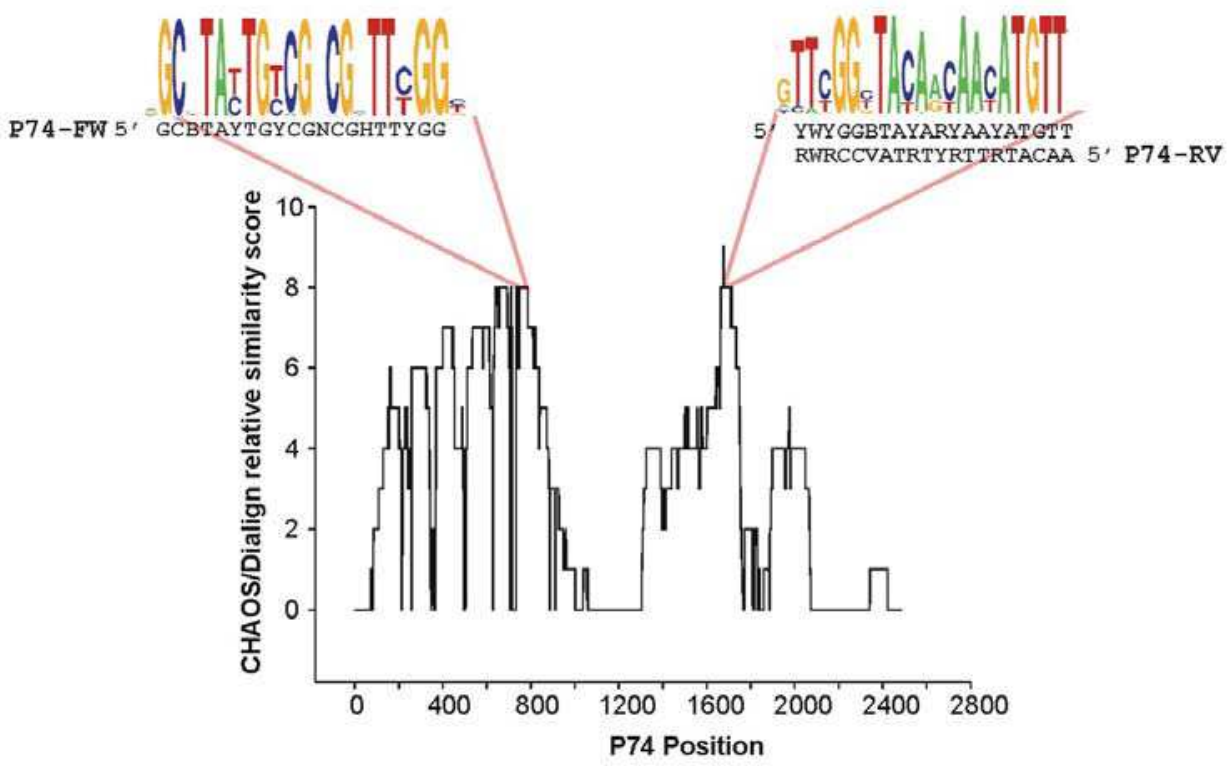



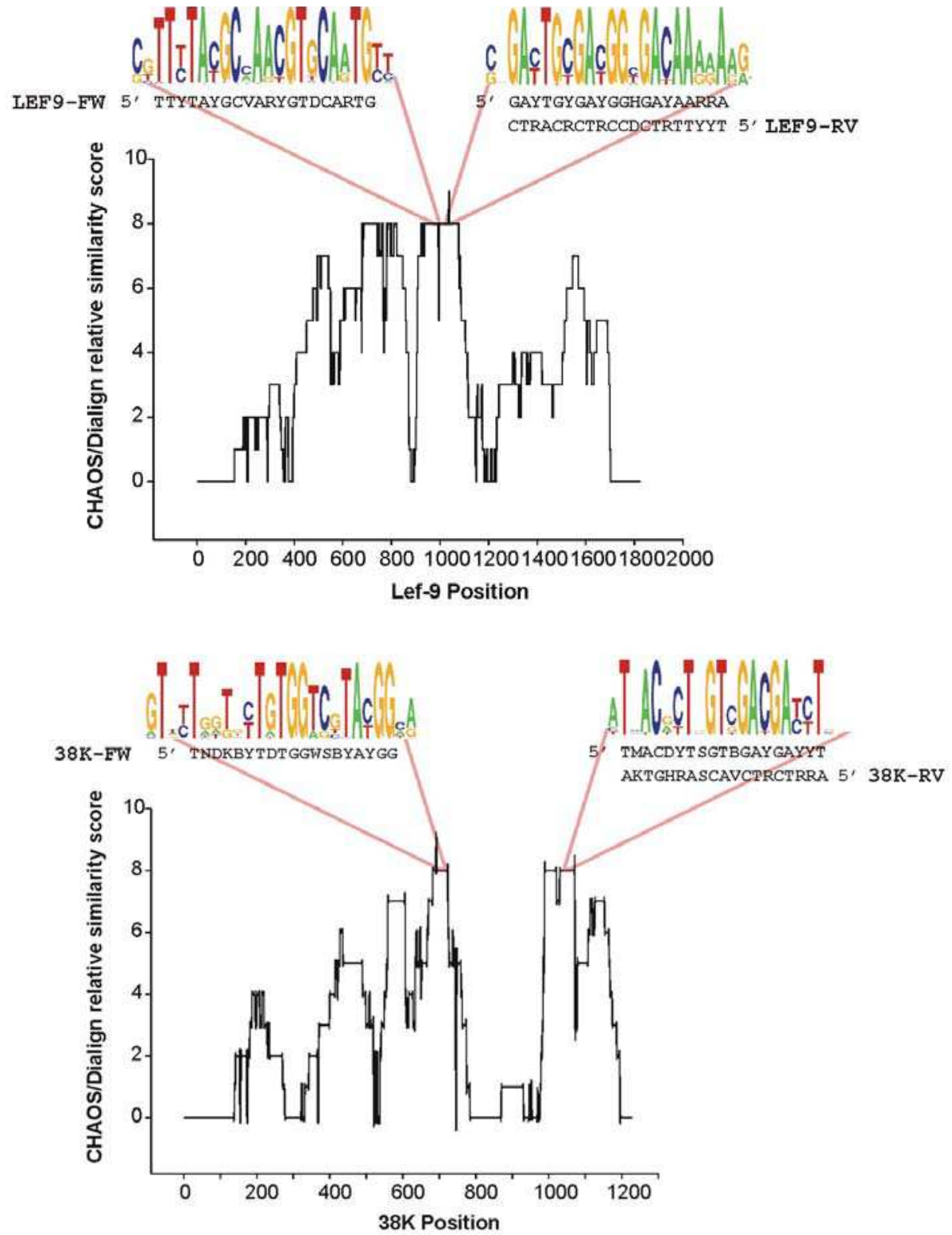

Fig. 4. Primer design for $p 74$, lef- 9 and $38 K$ genes. The orthologous sequences of $p 74$, lef- 9 and $38 \mathrm{~K}$ genes from Alpha and Betabaculovirus members were aligned by CHAOS/DIALIGN program (Brudno et al, 2004). A consensus line in the multiple alignment is a set of numbers (between 0-9) that roughly reflect the degree of local similarity among the sequences. These scores were used to generate plots. The regions with higher relative similarity were selected to design primers. These sequences are showed at the top in Sequence Logos (Crooks et al, 2004) 

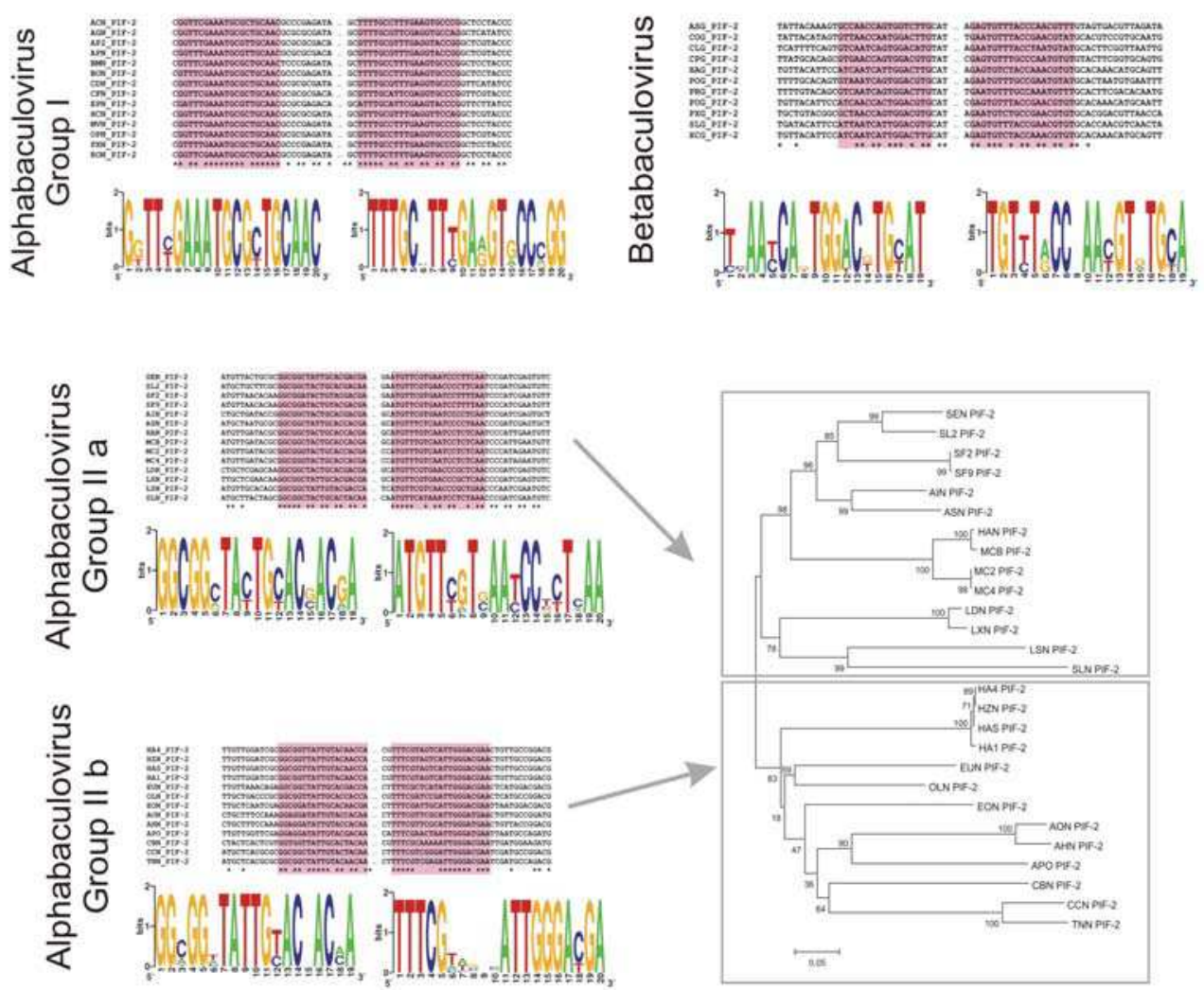

Fig. 5. Primer design for pif-2 gene. The orthologous sequences of pif-2 gene from Group I Alphabaculovirus or Group II Alphabaculovirus or Betabaculovirus members were aligned by T-Coffee program (Notredame et al, 2000; Poirot et al, 2003). The regions with higher similarity were selected to design primers. These sequences are showed at the bottom of each multiple alignment in Sequence Logos (Crooks et al, 2004). The cladogram was made with nucleotide sequences of pif-2 Group II Alphabaculovirus using MEGA 4. It showed a significative grouping in two lineages (Group II a and Group II b), which were considered to design primers. For $p 49$ sequence analysis a similar approach was conducted (data not shown)

Sets of proposed primers for MP-PCR would allow to detect the proper integrity of genomes in a baculovirus production (Table 3).

\begin{tabular}{|c|c|c|c|c|c|c|}
\hline Gene & Baculovirus & & \multicolumn{2}{c|}{ Primer sequence } & \multicolumn{3}{|c|}{ Product (bp) } \\
& & & 5' to 3 & ACN & LDN & CPG \\
\hline \multirow{2}{*}{ lef-9 } & \multirow{2}{*}{ Alpha + Beta } & FW & TTYTAYGCVARYGTDCARTG & 245 & 245 & 247 \\
& & REV & TYYTTRTCDCCRTCRCARTC & & & \\
\hline
\end{tabular}




\begin{tabular}{|c|c|c|c|c|c|c|}
\hline \multirow[t]{2}{*}{ Gene } & \multirow[t]{2}{*}{ Baculovirus } & & \multirow{2}{*}{$\begin{array}{c}\text { Primer sequence } \\
5^{\prime} \text { to } 3^{\prime}\end{array}$} & \multicolumn{3}{|c|}{ Product (bp) } \\
\hline & & & & $\mathrm{ACN}$ & LDN & CPG \\
\hline \multirow{2}{*}{$38 K$} & \multirow{2}{*}{ Alpha + Beta } & FW & TNDKBYTDTGGWSBYAYGG & \multirow{2}{*}{247} & \multirow{2}{*}{260} & \multirow{2}{*}{218} \\
\hline & & REV & ARRTCRTCVACSARHGTKA & & & \\
\hline \multirow{8}{*}{ pif-2 } & \multirow{4}{*}{$\begin{array}{l}\text { Alpha } \\
\text { Group I } \\
\text { Alpha } \\
\text { Group IIa }\end{array}$} & FW & GDTTYGAAATGCGYTGCAAC & \multirow{2}{*}{382} & \multirow{2}{*}{---} & \multirow{2}{*}{--- } \\
\hline & & REV & CCBGGHACYTCRAASGCAAA & & & \\
\hline & & FW & GGCGGVTAYTGYACBACVA & \multirow{2}{*}{347} & \multirow{2}{*}{347} & \multirow{2}{*}{---} \\
\hline & & REV & TTDARVGGRTTSACRAACAT & & & \\
\hline & \multirow{2}{*}{$\begin{array}{l}\text { Alpha } \\
\text { Group IIb }\end{array}$} & FW & GGMGGHTATTGYACNACVA & \multirow{2}{*}{---} & \multirow{2}{*}{260} & \multirow{2}{*}{---} \\
\hline & & REV & TCRTCCCAATBNSDDCGAAA & & & \\
\hline & \multirow{2}{*}{$\mathrm{Be}$} & FW & YYAAYCAKTGGWCDTGYAT & \multirow{2}{*}{306} & \multirow{2}{*}{306} & \multirow{2}{*}{306} \\
\hline & & REV & TRCAHACRTTNGGYARACA & & & \\
\hline \multirow{2}{*}{$p 74$} & \multirow{2}{*}{ Alpha + Beta } & FW & GCBTAYTGYCGNCGHTTYGG & \multirow{2}{*}{824} & \multirow{2}{*}{830} & \multirow{2}{*}{935} \\
\hline & & REV & AACATRTTRYTRTAVCCRWR & & & \\
\hline \multirow{6}{*}{$p 49$} & \multirow{2}{*}{$\begin{array}{l}\text { Alpha } \\
\text { GroupI }\end{array}$} & FW & AGTYTATTTGAYYTRAAARA & \multirow{2}{*}{1284} & \multirow{2}{*}{--- } & \multirow{2}{*}{--- } \\
\hline & & REV & ACTTTCGTAATCACCTCTTA & & & \\
\hline & \multirow{2}{*}{$\begin{array}{l}\text { Alpha } \\
\text { GroupII }\end{array}$} & FW & TAYGCNACNAAYYTKTTYGT & --- & 970 & --- \\
\hline & & REV & AATCWCCTCTTATRAWWARAT & & & \\
\hline & Bet & FW & CARMGVGAYTAYRTHTWYGA & & & 596 \\
\hline & & REV & AATAARYTYRVWAHVGTRTT & & & ס \\
\hline
\end{tabular}

Table 3. Primer sequences to perform a MP-PCR assay. The table contains all the primer sequences designed by two different approaches and the hypothetical length of amplified fragments using the genome prototypes as reaction template. The specificity of annealing and the size of the amplicons were verified using jPCR (Kalendar et al, 2009). FW: forward primer. REV: reverse primer. Ambiguities are indicated in IUPAC code, $B=C, G, T ; D=A, G, T$; $\mathrm{H}=\mathrm{A}, \mathrm{C}, \mathrm{T} ; \mathrm{K}=\mathrm{G}, \mathrm{T} ; \mathrm{M}=\mathrm{A}, \mathrm{C} ; \mathrm{N}=\mathrm{A}, \mathrm{C}, \mathrm{G}, \mathrm{T} ; \mathrm{R}=\mathrm{A}, \mathrm{G} ; \mathrm{S}=\mathrm{C}, \mathrm{G} ; \mathrm{V}=\mathrm{A}, \mathrm{C}, \mathrm{G} ; \mathrm{W}=\mathrm{A}, \mathrm{T} ; \mathrm{Y}=\mathrm{C}, \mathrm{T}$

\section{Conclusion}

Integrated control management of agricultural pests requires the combination of different insecticide strategies. Among them, the use of baculovirus is an excellent solution as biological control agent. There are many known members of this viral family, with dozens of sequenced genomes. Some of the limitations that exist in their massive application are given by their time of action and modes for their production. Regarding the latter, quality control methodologies are emerging as essential to ensure proper development and formulation. In view of that, in this work are proposed a series of primers for PCR assays 
that would amplify a fragment profile appropriate to certify the genomic integrity and identity of batch production. Furthermore, adding other specific primers (e.g. specific of transgenes) could be confirmed genotypic stability of genetically modified viruses.

Also, the methodology here proposed could be used to characterize new baculoviral isolates, which could be used as bioinsecticides and produced and controlled without the knowledge of their genome sequences.

\section{Acknowledgment}

This work was supported by research funds from Agencia Nacional de Promoción Científica y Técnica (ANPCyT) and Universidad Nacional de Quilmes. PDG is member of the Research Career of CONICET (Consejo Nacional de Ciencia y Tecnología); MNB holds a postdoctoral fellowship of CONICET, SABM holds a fellowship of CONICET and MJG holds a fellowship of CICBA.

\section{References}

Agathos, S.N. (2007). Development of serum-free media for lepidopteran insect cell lines. Methods Mol Biol. Vol 388, pp. 155-186. ISSN: 1064-3745.

Brudno, M.; Steinkamp, R.; Morgenstern, B. (2004). The CHAOS/DIALIGN WWW server for multiple alignment of genomic sequences. Nucleic Acids Res., 2004 Jul 1, vol. 32, pp. 4144. ISSN 0305-1048.

Christian, P.D.; Gibb, N.; Kasprzak, A.B.; Richards, A. (2001). A rapid method for the identification and differentiation of Helicoverpa nucleopolyhedroviruses (NPV Baculoviridae) isolated from the environment. J Virol Methods, 2001 Jul, vol 96, pp. 5165. ISSN: 0166-0934.

Christou, P.; Capell, T.; Kohli, A.; Gatehouse, J.A.; Gatehouse, AM. (2006). Recent developments and future prospects in insect pest control in transgenic crops. Trends Plant Sci, 2006 Jun, vol 11, pp. 302-308. ISSN: 1360-1385.

Crouch, E.A.; Cox, L.T.; Morales, K.G.; Passarelli, A.L. (2007). Inter-subunit interactions of the Autographa californica M nucleopolyhedrovirus RNA polymerase. Virology, 2007 Oct 25, 367, pp. 265-274. ISSN: 0042-6822.

De Lima, M.E.; Figueiredo, S.G.; Pimenta, A.M.; Santos, D.M.; Borges, M.H.; Cordeiro, M.N.; Richardson, M.; Oliveira, L.C.; Stankiewicz, M.; Pelhate, M. (2007). Peptides of arachnid venoms with insecticidal activity targeting sodium channels. Comp Biochem Physiol C Toxicol Pharmacol. 2007 Jul-Aug, vol 146, pp. 264-79. ISSN: 1532-0456.

de Moraes, R.R.; Maruniak, J.E.; Funderburk, J.E. (1999). Methods for detection of Anticarsia gemmatalis nucleopolyhedrovirus DNA in soil. Appl Environ Microbiol, 1999 Jun, vol 65, pp. 2307-2311. ISSN: 0099-2240.

Eberle, K.E.; Sayed, S.; Rezapanah, M.; Shojai-Estabragh, S.; Jehle J.A. (2009). Diversity and evolution of the Cydia pomonella granulovirus. J Gen Virol, 2009 Mar, vol 90, pp. 662671. ISSN: 0022-1317.

Entwistle, P.F. (1998). A world survey of virus control of insect pests, pp. 189-200. In F. R. Hunter-Fujita, P.F. Entwistle, H.F. Evans, and N. E. Crook (ed.), “Insect Viruses and Pest Management". John Wiley \& Sons Ltd., Chichester, England. ISBN0-471-968781. 
Espinel-Correal, C.; Léry, X.; Villamizar, L.; Gómez, J.; Zeddam, J.L.; Cotes, A.M.; LópezFerber M. (2010). Genetic and biological analysis of Colombian Phthorimaea operculella granulovirus isolated from Tecia solanivora (Lepidoptera: Gelechiidae). Appl Environ Microbiol, 2010 Nov, vol 76, pp. 7617-1625. ISSN: 0099-2240.

Faktor, O. and Raviv, D. (1996). A polymerase chain reaction for the detection of nucleopolyhedroviruses in infected insects: the fate of the Spodoptera littoralis virus in Locusta migratoria. J Virol Methods, 1996 Sept, vol 61, pp. 95-101. ISSN: 0166-0934.

Crooks, G.E.; Hon, G.; Chandonia, J.M.; Brenner, S.E. (2004). WebLogo: a sequence logo generator. Genome Res, 2004 Jun, vol. 14, pp.1188-1190. ISSN: 1088-9051.

Gilligan, C.A. (2008). Sustainable agriculture and plant diseases: an epidemiological perspective. Philos Trans R Soc Lond B Biol Sci. 2008 Feb 27, vol 363, pp. 741-759. ISSN: 1471-2970.

Inceoglu, A.B.; Kamita, S.G.; Hammock, B.D. (2006). Genetically modified baculoviruses: a historical overview and future outlook. Adv Virus Res. 2006; vol. 68, pp. 323-360. ISSN: 0065-3527.

Jehle, J.A.; Blissard, G.W.; Bonning, B.C. (2006a). On the classification and nomenclature of baculoviruses: a proposal for revision, Archives of Virology, 2006 Jul, vol. 151, pp. 1257-1266. ISSN 0304-8608.

Jehle, J.A.; Lange, M.; Wang, H.; Hu, Z.; Wang, Y.; Hauschild, R. (2006b). Molecular identification and phylogenetic analysis of baculoviruses from Lepidoptera. Virology, 2006 Mar 1, vol 346, pp. 180-93. ISSN: 0042-6822.

Jinn, T.R.; Tu, W.C.; Lu, C.I.; Tzen, J.T. (2006). Enhancing insecticidal efficacy of baculovirus by early expressing an insect neurotoxin, LqhIT2, in infected Trichoplusia ni larvae. Appl Microbiol Biotechnol. 2006 Oct, vol. 72, pp. 1247-1253. ISSN: 0175-7598.

Jorio H.; Tran, R.; Meghrous, J.; Bourget, L.; Kamen, A. (2006). Analysis of baculovirus aggregates using flow cytometry. J Virol Methods. 2006 Jun, vol 134, pp. 8-14. ISSN: 0166-0934.

Kalendar, R.; Lee, D.; Schulman, A.H. (2009). FastPCR Software for PCR Primer and Probe Design and Repeat Search. Genes, Genomes and Genomics, vol 3, pp. 1-14. ISSN: 1749-0383. [http://primerdigital.com/fastpcr.html]

Lasa, R.; Williams, T.; Caballero, P. (2008). Insecticidal properties and microbial contaminants in a Spodoptera exigua multiple nucleopolyhedrovirus (Baculoviridae) formulation stored at different temperatures. J Econ Entomol, 2008 Feb, vol 101, pp. 42-49. ISSN: 0022-0493

Lee, H.Y.; Krell, P.J. (1992). Generation and analysis of defective genomes of Autographa californica nuclear polyhedrosis virus. J Virol. 1992 July, vol. 66, pp. 4339-4347. ISSN: 0022-538X.

Li, H.; Bonning, B.C. (2007). Evaluation of the insecticidal efficacy of wild-type and recombinant baculoviruses. Methods Mol Biol, vol 388, pp. 379-404. ISSN: 1064-3745.

Lin, T.; Yu, M.; Wu, W.; Yu, Q.; Weng, Q.; Yang, K.; Yuan, M.; Pang Y. (2010). Functional analysis of Spodoptera litura nucleopolyhedrovirus $p 49$ gene during Autographa californica nucleopolyhedrovirus infection of SpLi-221 cells. Virus Genes. 2010 Dec, vol 41, pp. 441449. ISSN: 0920-8569.

Manzán, M.A.; Aljinovic, E.M.; Biedma, M.E.; Sciocco-Cap, A.; Ghiringhelli, P.D. and Romanowski, V. (2008). Multiplex PCR and quality control of EpapGV production. Virus Genes, 2008 Oct, vol 37, pp. 203-211. ISSN: 0920-8569.

Mengual Gómez, D.L.; Belaich, M.N.; Rodríguez, V.A.; Ghiringhelli, P.D. (2010). Effects of fetal bovine serum deprivation in cell cultures on the production of Anticarsia gemmatalis multinucleopolyhedrovirus. BMC Biotechnol. 2010 Sep, vol. 15; 10:68. ISSN 1472-6750. 
Micheloud, G.A.; Gioria, V.V.; Pérez, G.; Claus J.D. (2009). Production of occlusion bodies of Anticarsia gemmatalis multiple nucleopolyhedrovirus in serum-free suspension cultures of the saUFL-AG-286 cell line: influence of infection conditions and statistical optimization. J Virol Methods. 2009 Dec, vol 162, pp. 258-266. ISSN: 0166-0934.

Miele, S.A.B.; Garavaglia, M.J.; Belaich, M.N.; Ghiringhelli, P.D. (2011). Baculovirus: Molecular Insights on Their Diversity and Conservation. International Journal of Evolutionary Biology. Vol. 2011, Article ID 379424, 15 pages, 2011 Feb. doi:10.4061/2011/379424. ISSN: 2090052X.

Moscardi, F. (1999). Assessment of the application of baculoviruses for control of Lepidoptera. Annu Rev Entomol. Vol 44, pp. 257-489. ISSN: 0066-4170.

Murillo, R.; Muñoz, D.; Williams, T.; Mugeta, N.; Caballero, P. (2006). Application of the PCRRFLP method for the rapid differentiation of Spodoptera exigua nucleopolyhedrovirus genotypes. J Virol Methods, 2006 Jul, vol 135, pp. 1-8. ISSN: 0166-0934.

Notredame, C.; Higgins, D.G.; Heringa, J. (2000). T-Coffee: A novel method for fast and accurate multiple sequence alignment. J Mol Biol, 2000 Sep 8, vol 302, pp. 205-17. ISSN: 00222836

Parola, A.D.; Sciocco-Cap, A., Glikmann, G., Romanowski, V. (2003). An immunochemical method for quantitation of Epinotia aporema granulovirus (EpapGV). J Virol Methods. 2003 Sep, vol 112, pp. 13-21. ISSN: 0166-0934.

Peng, K.; van Oers, M.M.; Hu, Z.; van Lent, J.W.; Vlak, J.M. (2010). Baculovirus per os infectivity factors form a complex on the surface of occlusion-derived virus. J Virol, 2010 Sep, vol 84, pp. 9497-504. ISSN: 0022-538X.

Poirot, O.; O'Toole, E.; Notredame, C. (2003). Tcoffee@igs: A web server for computing, evaluating and combining multiple sequence alignments. Nucleic Acids Res, 2003 Jul 1, vol 31, pp. 3503-3506. ISSN 0305-1048.

Rodríguez, V.A.; Belaich, M.N.; Gómez, D.L.; Sciocco-Cap, A; Ghiringhelli, P.D. Identification of nucleopolyhedrovirus that infect Nymphalid butterflies Agraulis vanillae and Dione juno. J Invertebr Pathol, 2011 Feb, vol 106, pp. 255-262. ISSN: 0022-2011.

Rohrman, G.F. (2008). Baculovirus Molecular Biology, National Library of Medicine (US), NCBI, Bethesda, Md, USA, 2008.

Rosinski, M.; Reid, S.; Nielsen, L.K. (2002). Kinetics of baculovirus replication and release using real-time quantitative polymerase chain reaction. Biotechnol Bioeng, 2002 Feb, vol 77, pp. 476-480. ISSN: 0572-6565.

Rowley, D.L.; Farrar, R.R. Jr; Blackburn, M.B.; Harrison, R.L. (2010). Genetic and biological variation among nucleopolyhedrovirus isolates from the fall armyworm, Spodoptera frugiperda (Lepidoptera: Noctuidae). Virus Genes, 2010 Jun, vol 40, pp. 458-468. ISSN: 0920-8569.

Shen, C.F.; Meghrous, J.; Kamen, A. (2002). Quantitation of baculovirus particles by flow cytometry. J Virol Methods. 2002 Sep, vol 105, pp. 321-30. ISSN: 0166-0934.

Simón, O.; Williams, T.; López-Ferber, M.; Caballero, P. (2004). Genetic structure of a Spodoptera frugiperda nucleopolyhedrovirus population: high prevalence of deletion genotypes. Appl Environ Microbiol, 2004 Sep, vol 70, pp. 5579-5588. ISSN: 0099-2240.

Song, J.; Wang, R.; Deng, F.; Wang, H.; Hu, Z. (2008). Functional studies of per os infectivity factors of Helicoverpa armigera single nucleocapsid nucleopolyhedrovirus. J Gen Virol, 2008 Sep, vol 89, pp. 2331-2338. ISSN: 0022-1317.

Szewczyk, B.; Hoyos-Carvajal, L.; Paluszek, M.; Skrzecz, I., Lobo de Souza, M. (2006). Baculoviruses, re-emerging biopesticides. Biotechnol Adv. 2006 Mar-Apr, vol. 24, pp. 143-60. ISSN: 0734-9750. 
Theilmann, D.A.; Blissard, G.W.; Bonning, B.C.; Jehle, J.A.; O'Reilly, D.R.; Rohrmann, G.F.; Thiem, S.M.; and Vlak, J.M. Baculoviridae, In C. M. Fauquet, M. A. Mayo, J. Maniloff, U. Desselberger, and L. A. Ball. (2005). Virus Taxonomy: (eds.), Taxonomy of Viruses: VIII Report of the International Committee on Virus Taxonomy. Elsevier, London, pp. 177-185.

van Beek, N.; Davis, D.C. (2007). Baculovirus insecticide production in insect larvae. Methods Mol Biol. 2007, vol 388, pp. 367-378. ISSN: 1064-3745.

van Oers, M. M. and Vlak, J. M. (2007). Baculovirus genomics. Current Drug Targets. 2007 Oct vol. 8, pp. 1051-1068. ISSN 1389-4501.

Wang, C.H.; Yang, H.N.; Liu, H.C.; Kou, G.H.; Lo, C.F. (2000). Nested polymerase chain reaction and in situ hybridization for detection of nucleopolyhedrosis. J Virol Methods, 2000 Jan, vol 84, pp. 65-75. ISSN: 0166-0934.

Wang, H.; Deng, F.; Pijlman, G.P.; Chen, X.; Sun, X.; Vlak, J.M.; Hu, Z. (2003). Cloning of biologically active genomes from a Helicoverpa armigera single-nucleocapsid nucleopolyhedrovirus isolate by using a bacterial artificial chromosome. Virus Res, 2003 Nov, vol 97, pp. 57-63. ISSN: 0168-1702.

Wu, W.; Liang, H.; Kan, J.; Liu, C.; Yuan, M.; Liang, C.; Yang, K.; Pang, Y. (2008). Autographa californica multiple nucleopolyhedrovirus 38K is a novel nucleocapsid protein that interacts with VP1054, VP39, VP80, and itself. J Virol, 2008 Dec, vol 82, pp. 12356-12364. ISSN: 0022-538X. 


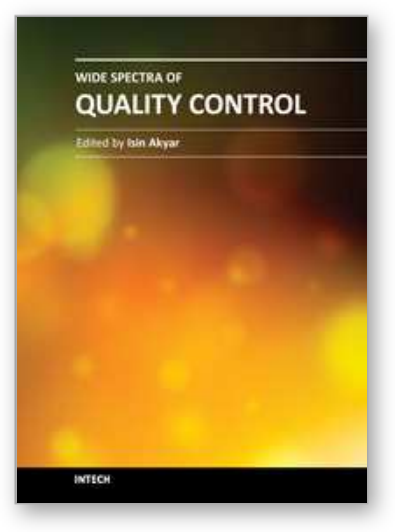

\author{
Wide Spectra of Quality Control \\ Edited by Dr. Isin Akyar
}

ISBN 978-953-307-683-6

Hard cover, 532 pages

Publisher InTech

Published online 07, July, 2011

Published in print edition July, 2011

Quality control is a standard which certainly has become a style of living. With the improvement of technology every day, we meet new and complicated devices and methods in different fields. Quality control explains the directed use of testing to measure the achievement of a specific standard. It is the process, procedures and authority used to accept or reject all components, drug product containers, closures, in-process materials, packaging material, labeling and drug products, and the authority to review production records to assure that no errors have occurred. The quality which is supposed to be achieved is not a concept which can be controlled by easy, numerical or other means, but it is the control over the intrinsic quality of a test facility and its studies. The aim of this book is to share useful and practical knowledge about quality control in several fields with the people who want to improve their knowledge.

\title{
How to reference
}

In order to correctly reference this scholarly work, feel free to copy and paste the following:

Solange Ana Belén Miele, Mariano Nicolás Belaich and Pablo Daniel Ghiringhelli (2011). Quality Control of Baculoviral Bioinsecticide Production, Wide Spectra of Quality Control, Dr. Isin Akyar (Ed.), ISBN: 978-953307-683-6, InTech, Available from: http://www.intechopen.com/books/wide-spectra-of-quality-control/qualitycontrol-of-baculoviral-bioinsecticide-production

\section{INTECH}

open science | open minds

\author{
InTech Europe \\ University Campus STeP Ri \\ Slavka Krautzeka 83/A \\ 51000 Rijeka, Croatia \\ Phone: +385 (51) 770447 \\ Fax: +385 (51) 686166 \\ www.intechopen.com
}

\author{
InTech China \\ Unit 405, Office Block, Hotel Equatorial Shanghai \\ No.65, Yan An Road (West), Shanghai, 200040, China \\ 中国上海市延安西路65号上海国际贵都大饭店办公楼 405 单元 \\ Phone: +86-21-62489820 \\ Fax: $+86-21-62489821$
}


(C) 2011 The Author(s). Licensee IntechOpen. This is an open access article distributed under the terms of the Creative Commons Attribution 3.0 License, which permits unrestricted use, distribution, and reproduction in any medium, provided the original work is properly cited. 